\title{
The Relationship Between Organizational Stress And Organizational Identification: A Research on The Shopping Center Employees
}

\author{
Dr. MITHAT TURHAN \\ Mersin University \\ Applied Technology and Management School of Silifke \\ Email: mithatt@mersin.edu.tr \\ Dr. ONUR KÖPRÜLÜ \\ Applied Technology and Management School of Silifke \\ Email: onurkoprulu@gmail.com
}

\begin{abstract}
The main objective of this research is to determine the effects of stress factors on the organizational identification process of shopping center employees. Population of this study is consisted of shopping center employees in Ankara. Easy sampling method was used in this research. Survey was used as the data gathering method in this study. 156 surveys out of 200 were evaluated. On the other hand, correlation and regression alalyzes were conducted to test the hypotheses of the research model According to regression coefficient values of sub-dimensions of organizational stress managers, Tangible Possibilities and colleagues dimensions have statistical significance with negative effect on organizational identification. According to the findings on literaure review, it is evaluated that there are limited number of scientific researches trying to figure out the relationship between organizational identification and organizational stress. Therefore, this research aim to fulfill the gap in this field and contribute to scientific knowledge.
\end{abstract}

Keywords: Organizational Stress, Organizational Identification, Shopping Center Employees.

\section{Introduction}

Shopping centers are of great importance both for consumers and for the entire society due to the capacity of their commercial activities. Value creating effect in GDP and the substantial contribution of economic activities have opened a road for Shopping centers to be more attentively analysed. According to the data for 2019 provided by Council of Shopping Centers, there are 436 shopping centers in Turkey currently active with 27 billion USD indorsement value and 400.000 employees (AYD, 2019).

Shopping center employees play a significant role for trying to provide the best service starting from the welcoming of customers, presentation of goods and services while endeavouring to increase the market share of their companies. Nowadays, responsibilities of shopping center employees have dramatically varied and increased in terms of a conprehensive management process such as promoting new sales methods and achieving high customer loyalty levels in addition to reach the goals of traditional sales management procedures.

Organizations have experienced a fast transformation process in conjunction with the fundamental transformation of information and communication Technologies. Therefore, they have realized the importance of the adaption of this transformation process in order to gain competitive advantage against competitors. Transformation of organizational structure and perception of management process is 
considered to be the most significant step to be taken so as to continue their organizational existence in the inreasing competitive environment. In this context, organizations having hard hierarchical structures have been transformed into more imminent structure by flattening. Moreover, working in cross-functional teams have been established. In addition, a new organizational structure focusing on the cooperation of departments with different borders has been constituted. Increasing concerns about high level of cometitiveness and worries about decreasing the costs have pioneered organizations to be more creative and more competitive. These modifications and implementations in organizational structure inhibited the employees and caused high level of stress. Garg and Saxena (2020) pointed out that, employees under stress are less effective in their working environment and showing tendency of leaving the job as soon as possible. All these negative circumstances caused by stress also brought back undesirable spiritual and material costs for organizations (Ganster et all, 1982: 533). Sullivan and Bhagat (1992:353) emphasized that the contribution of employees to the organization will be decreased due to lack of performance and job satisfaction.

\section{Literature Review}

Stress, which has been examined for a very long time period, has also been analyzed by Medicine, engineering and organizational behavior. Organizations are experiencing the increasing disadvantageous impacts of stress such as a decrease in organizational productivity and efficiency. The word "stress" originally comes from the word "Estricia" in Latin. Stress was used as describing curse, disaster or trouble in 17th century and used as pressure and rough in the 19th century (Ertekin, 1993: 148). It is not always appropriate to use stress for adressing and unpleasant and vicious situations. Stress plays an important motivational role for success. In addition, Bernard has explained stress in two manners as pleasant (Eustress) and unpleasant (Dystress) stress. In this sense, dystress can be identified as the feeling of subjective discomfort caused by unpleasant situations (Ertekin, 1998:148). Furthermore, stress can also be explained as the interaction of a person with the environment, evaluation process of a specific situation and the endeavouring process of accomplishing a problem by a person (Fletcher, Hanton and Mellalieu, 2006: 9). Hence, stress is relevant to a shift in the environment of a person or the impacts of this shift on a person (Eren, 2010: 291).

Organizational stress, on the other hand, emerges as a consequence of the interaction between individual and organization which leads to a situation in which the individual is forced to diverge from the normal activity Organizaitonal stress is identified as the socio-psychological stress associated with the work.

Organizaitonal stress is described as the conceptualization of employee and the working environment of the employee (Woodman and Hardy, 2001). Another definition mentions that organizational stress is the reaction of harmony against external conditions that causes physical, physchological and organizational deviations of the members of the organization (Yamuç and Türker, 2015: 393). Organizational stress neither involves in working environment nor in the individuals. Organizational stress derives from the cognitive evaluation of an individual concerning the working environment (Woodman and Hardy, 2001). There are various factors in the organizational life that causes stress. These factors are closely related to organizational structure, context of the work and relations among employers of the organization. Factors endengering stress, also interact with eachother and affect the physical and spiritual conditions of employers. All these factors forcing the psychological integrity, self-respect and self-confidence of employees evoke stress. Business as a part of the organization comes into pominence as the main effect. Thus, stress ingenerates a restrictive and compulsive effect on employees (Güney, 2011:405).. As a consequence of technological innovations, employers strarted to prefer machinery for some kind of tasks rather than employees. Therefore, it is not necessary for eployees to specify any kind of absolote decline in the performance or disloyalty of employers. Physiclological conditions of employees are negatively affected by increasing level of stress caused by the concerns of employees thoughts about both loosing their own work and loosing their colleagues. Existence of excess working conditions, unfair performance evaluation mechanism and unfair promotion system can be pointed out as the main factors that pave the 
way for organizational stress. Moreover, role conflict and uncertainity, inadequate information, poor physical conditions, insufficient opportunities of promotion, isolation from the decision-making systrems, inequality of income levels, excess working conditions, lack of information, perceived control level, vertical and horizontal relationships among employees are also of great importance.

Individuals perform high levels of productivity in case they feel satisfaction about their work and working environment. Thus, all these facts will negatively affect the employees' job satisfaction levels and their performance (Sullivan and Bhagat, 1992: 354-355; Woodman and Hardy, 2001: 208; Tavakoli, 2010:1795; Altan, 2018: 142-143). It is articulated that stress triggers the intention to leave the job, increase in the discontinuity to job, high blood pressure, cardiovascular diseases, ulcer, cancer, partial or complete stroke (Ataman, 2001: 487). In addition, employees facing stress tend to come up with depression and conflict with other employees which can increase the possibility of occupational accident (Jain and Cooper, 2012:156). Furthermore, stress can also cause high level of alcohol and cigarette consumption, sleeplessness, disharmony in the working environment, emotional imbalance, dissatisfaction at work,

In parallel with mergers, acquisitions and developments in information technologies, structural changes in the organization pose a threat to employees' organizational belongings. Hence, the importance of the concept of identification has recently been dramatically increasing both for organizations and employees' health and wellbeing (Van Knippenberg and Van Schie, 2000: 137). Organizational identification concept was not paid attention by researchers since 1970s like othe concepts such as job satisfaction, job motivation and organizational commitment. First detailed model concerning organizational identification was expressed by Marc and Simon (1958) and just a few research focused on this topic in the following 20 years. In 1970s, researchers started to consider organizational identification as a component of attitudinal organizational commitment and used this concept as a synonym of attitudinal organizational commitment (Riketta, 2005:358). Maer and Ashfort tried to explain organizational identification on the basis of social identity theory in order to eliminate the confusion of organizational identification and organizational commitment faced by reaserchers. While Social identity Theory denotes individuals' state of belonging to a group (Gürlek and Tuna, 2018: 40) or collaborating with the group, organizational identification is established on the basis of the development of individuals' organizational behavior and attitude. According to social identity theory, individuals show tendency to categorize both temselves and others others for their membership, sex and age.

Consequently, individuals put themselves and others into stereotypes according to this categorization. Theory depends on the integration or the abstraction of individuals from the group according to the similarities of individuals among categorized groups in terms of their prototypical characteristics. In this context, social identification is the perception of an individual about a categorized group. Individuals have the perception of the integration of the group's destiny with his or her own destiny with social identification. Therefore, while the common fate is being shared, success and failure are also being experienced and owned by individuals (Mael and Ashforth, 1992: 105). Individuals meet their self ashancement needs, safety needs and affiliation needs with socail identification (Elsbach, 1999: 166). As a consequnce of the identification, individuals have share in the accomplishments emerged beyond their own power and they can stay away from the activities that might harm them in the process of accomplishment. According to this perspective, organizational identification is evaluated as a form of social identification that an individual describes himself in terms of his organizational membership to a group (Mael and Ashforth, 1992: 105). Organizational identification has been reinvented and many theoretical analyses has been performed in the following years by organizational behavior researchers on the basis of the framework developed by Mael and Ashforth. Organizational identification is described as the perception of an individual as a member of an organization while acting in harmony with the organization (Mael and Ashforth, 1992: 104). In this sense, appreciation of an individual against his group and placing emotional emphasis on this conceptual membership has increased its importance. 
Organizational identification occurs when an individual feels a connection to his organization, perceives himself as united with the organization and devines himself appertain to the organization (Fonner and Roloff, 2012: 216). Conceptual belonging of an individual to a group depends on the perception of the amount of favor between individual and the organization. An individual can be acknowledged as a member in case he perceives himself as a part of the group and feels the sense of belonging. The cognitive connection between the individual and the group is constituted when the individual draws the borders among the group he thinks he is involved in and the other group he is not involved in while he is categorizing himself as a member of the group. The importance given by the individual to the group points out the appreciaiton of the individual to be a member of the group. In addition this appreciation is of great importance to create a positive image for the group that the individual is involved in (Smidts, Pruyn and Van Riel, 2001: 6).

Employees get great benefits regarding the organizaitonal process by organizational identification. Employees tendency to act with the organization's goals is increasing in parallel with the increase in the level of organizational identification (Van Knippenberg and Van Schie, 2000: 137). Organizational identification provides plenty of both individual and organizational benefits. Employees achieve higher self-confidence and perceive themselves more precious while obtaining higher satisfaction from their working conditions with organizational identification. Also motivational levels of employees increase with the organizaitoşnal identification. Employees adopted organizational identification, are perceived to have higher performance and derserve to get promotion according to managers. Organizational benefits of organizational identificaiton can be mentioned as higher level of fidelity of employees to the organization, extra role plays than expected from them and simplifying the controls of organizational members by employees (Elsbach, 1999: 169-170).

\section{Theoretical Framework}

Empirical findings regarding the organizational identification such as perceived organizational prestige, given rewards, motivative job for employees, fair performance evaluation, convincing salaries, receiving respect expose that stress actors that arise from organizational adjustments and implementations affect the identification of the individual with the organization (Elsbach, 1999: 169-170). Organizational identification is the process of being more integrated and more compatible in terms of the goals of both the organization and the employees (Hall, Schneider and Nygren, 1970: 176). Individuals accomplish the actions that serve for the organizational benefits and they act with the perspective of organization to cases and events in case they identify themselves with the organization It is emphasized that together with the organizational identification, there is an increase in the organizational performance with organizational citizenship behaviors. In addition, it is also put forward that there is a negative relationship between organizational identification and the intention to quit job (Van Knippenberg and Van Schie, 2000: 143; Mael and Ashforth, 1995: 309; ). On the other hand, organizational identification is revealed as the process of developng the sense of belonging and interpreting the work as significant by employees (Kreiner and Ashforth, 2004: 3).

Organizational identification increases the possibility of employees not to quit by hindering the weakening of organizational commitment. Employees desire to stay away from the circumstances that make them feel unhappy and desire to be involved in the circumstances that make them feel happy. Therefore, employees decide whether keep working on their organization due to working conditions at work. Employees, otherwise would decide to quit job if their desires, expectations and conditions at work are not met. It is specified that there is a correlation between working condiitons and the intention to quit the job. Shifts in organizational life also brings about long working hours, isolation of colleagues, harder goals to achieve. Furthermore, employees exprience too much ambiguity due to inadequate information and shifts in colleagues and managers in terms of working conditions, production process and working hours. These factors ingenerates employees to face stress (Cranwell-Ward and Abbey, 2005: 11). The main obstacles for employees to establish the organizational identification can be expressed as unprovided carrier 
expectations, wages, excess working conditions, lack of information, relaitonship between lower and upper level employees (Houkes vd., 2001: 4; Coetzee ve van Dyk, 2018). Thus, appropriate administration of stress factors will contribute to maximize the benefits provided by employees. Implementation of stress management strategies and understanding the organizational change in order to adapt environmental shifts is useful for organizational identification of employees ( $\mathrm{Yu} ; 2009: 17)$.

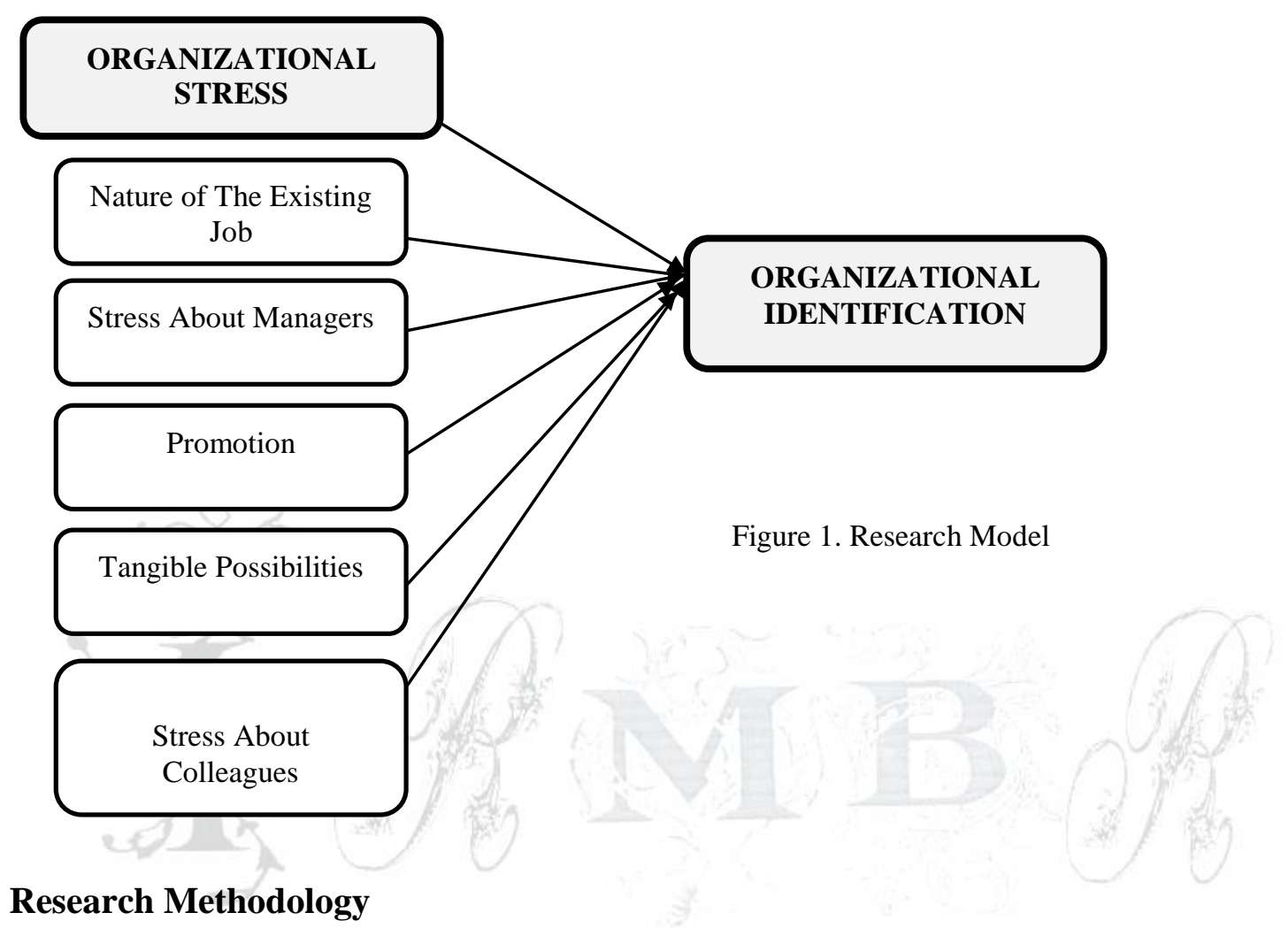

The main objective of this research is to determine the effects of stress factors on the organizational identification process of shopping center employees. Population of this study is consisted of shopping center employees in Ankara. Easy sampling method was used in this research. Survey was used as the data gathering method in this study. 156 surveys out of 200 were evaluated.

The survey was consisted of 3 main sections. In the first section, demographic features of the participants such as age, sex, education, time of experience and marital status were examined. Second section of the study focused on gathering data on the determination of employees' stress levels on the basis of former research results conducted by Solakoğlu 2007 referring (Davis \& Newstorm 1988; 2004; Kreitner \& Kinicki 1989). 28 clauses and 5 dimensions in the survey, concentrated on collecting data about the nature of the existing job, stress about the managers, promotion, tangible possibilities and stress about colleagues. Finally, the third section was consisted of 6 clauses about organizational identification developed by Mael and Ashfort (1992). Cronbach's Alpha coefficients were calculated to test the internal consistency of the scales used in the survey. The nature of the existing job, stress about the managers, promotion, tangible possibilities and stress about colleagues were the sub-dimensions of organizational stress scale. Thus, Cronbach's Alpha coefficients for these dimension were respectively calculated as 0.816- 0,630- 0,796-, 0,861-0,656, 0,782. Cronbach's Alpha coefficient of organizational identification scale was 0,826. It is possible to evaluate that these values mentioned above appeared in reasonable levels for the reliability (Uzunsakal ve Y1ld1z, 2018: 19). On the other hand, correlation and regression alalyzes were conducted to 
test the hypotheses of the research model. SPSS 20 demo version for Windows was used to alayze the the Data, collected by the survey. Thus, research model as shown on Figure 1 below was evaluated and the validity of the hypotheses were tested.

H1: There is a negative relationship between the nature of the existing job and organizational identification.

$\mathrm{H} 2$ : There is a negative relationship between employees' stress about the managers and organizational identification.

H3: There is a negative relationship between employees' perceptions about promotion and organizational identification.

H4: There is a negative relationship between employees' colleagues and organizational identification.

H5: There is a negative relationship between stress perceptions about colleagues and organizational identification.

H6:Stress perceptions of employees on the nature of the existing job negatively affects organizational identification.

H7: Stress perceptions of employees on managers negatively affects organizational identification.

H8: Stress perceptions of employees promotions negatively affects organizational identification.

H9: Stress perceptions of employees on tangible possibilities negatively affects organizational identification.

H10: Stress perceptions of employees on colleagues negatively affects organizational identification.

\section{Research Findings}

Distribution of the individuals involved in the sampling group is shown in Table 1 below. According to the findings indicated in Table 1, 52,6\% of the participants were men, 60,3\% were single, 45,5\% were in the age between 18 and 24 and 43,6 were having high school degree.

Table 1. Distribution of the Participants According to Demographic Features

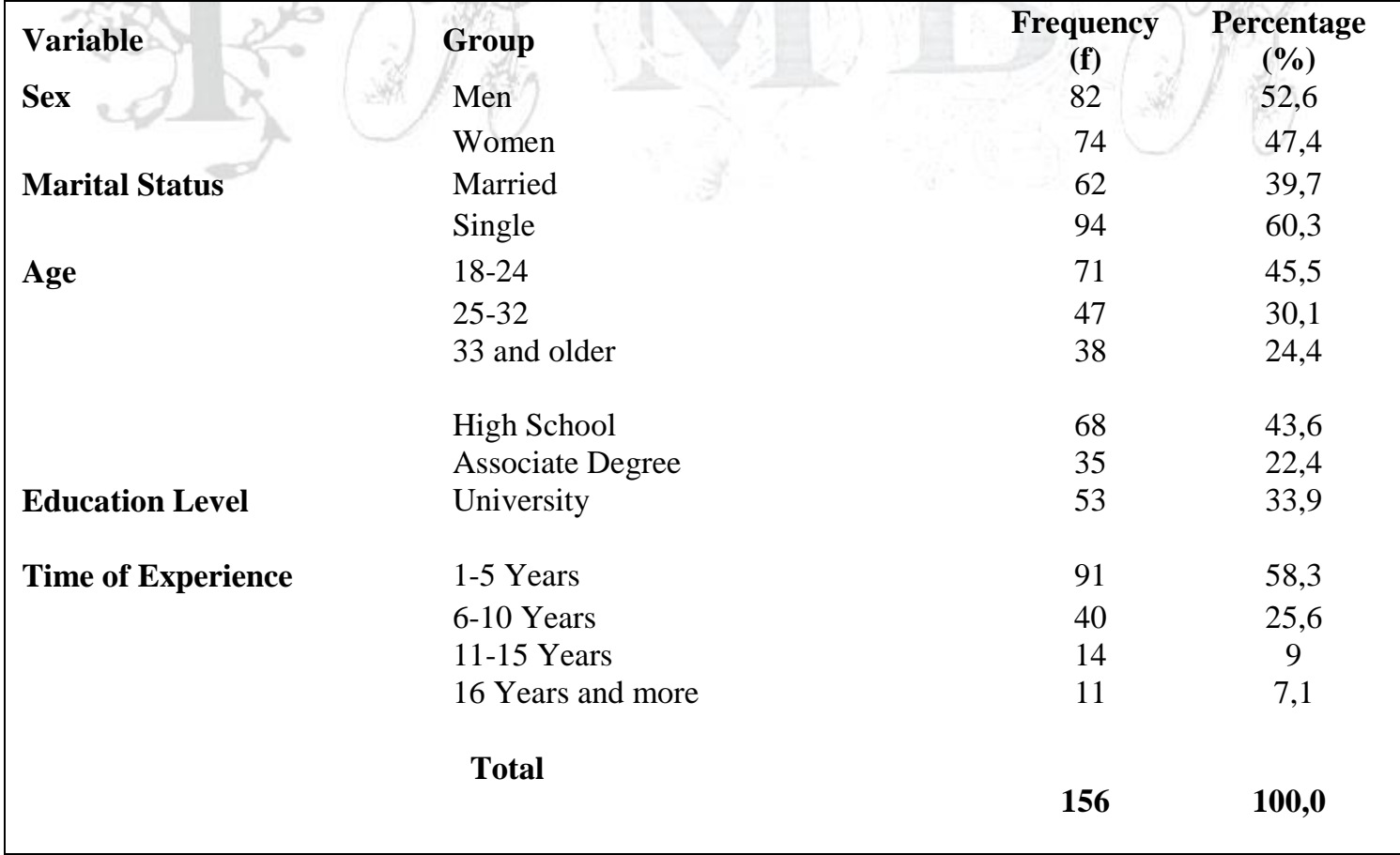


Table 2. Statistics on Sub-dimensions of Organizational Stress and Organizational Identification

\begin{tabular}{|l|c|c|c|}
\hline & Frequency & Mean & $\begin{array}{c}\text { Standard } \\
\text { Deviation }\end{array}$ \\
\hline Nature of Existing Job & 156 & 2,85 &, 99 \\
\hline Managers & 156 & 3,02 &, 91 \\
\hline Promotion & 156 & 2,81 &, 95 \\
\hline Tangible Possibilities & 156 & 3,08 &, 94 \\
\hline Colleagues & 156 & 3,12 &, 68 \\
\hline Organizational Identification & 156 & 3,57 &, 93 \\
\hline
\end{tabular}

Table 2 shows the means of sub-dimensions of organizational stress according to the results of analyzes. Thus, low scores gathered from sub-dimensions of organizational stress indicates high organizational stress while higher scores indicate lower organizational stress.

Table 3. Correlations Between Sub-dimensions of Organizational Stress and Organizational Identificaiton

\begin{tabular}{|c|c|c|c|c|c|c|c|}
\hline & & $\begin{array}{c}\text { Nature of } \\
\text { Existing } \\
\text { Job }\end{array}$ & Managers & Promotion & $\begin{array}{c}\text { Tangible } \\
\text { Possibilities }\end{array}$ & Colleagues & Identification \\
\hline \multirow{2}{*}{$\begin{array}{l}\text { Nature of } \\
\text { Existing Job }\end{array}$} & $\begin{array}{l}\text { Pearson } \\
\text { Correlation } \\
\text { Sig. (2- } \\
\text { tailed) }\end{array}$ & 1 & $\begin{array}{l}, 476^{* * *} \\
, 000\end{array}$ & $\begin{array}{l}, 529^{* *} \\
, 000\end{array}$ & $\begin{array}{l}, 621^{* *} \\
, 000\end{array}$ & $\begin{array}{l}, 452^{* *} \\
, 000\end{array}$ & $\begin{array}{l}, 164^{*} \\
, 140\end{array}$ \\
\hline & $\mathrm{N}$ & 156 & 156 & 156 & 156 & 156 & 156 \\
\hline \multirow{3}{*}{ Managers } & $\begin{array}{l}\text { Pearson } \\
\text { Correlation }\end{array}$ &, $476^{* *}$ & 1 &, $582^{* *}$ &, $585^{* *}$ &, $369^{* *}$ &,- 004 \\
\hline & $\begin{array}{l}\text { Sig. (2- } \\
\text { tailed) }\end{array}$ &, 000 & & ,000 & ,000 & ,000 & ,961 \\
\hline & $\mathrm{N}$ & 156 & 156 & 156 & 156 & 156 & 156 \\
\hline \multirow{3}{*}{ Promotion } & $\begin{array}{l}\text { Pearson } \\
\text { Correlation }\end{array}$ &, $529^{* *}$ &, $582^{* *}$ & 1 &, $717^{* *}$ &, $524^{* *}$ &, $162^{*}$ \\
\hline & $\begin{array}{l}\text { Sig. (2- } \\
\text { tailed) }\end{array}$ & ,000 & ,000 & & ,000 & ,000 & , 144 \\
\hline & $\mathrm{N}$ & 156 & 156 & 156 & 156 & 156 & 156 \\
\hline \multirow{3}{*}{$\begin{array}{l}\text { Tangible } \\
\text { Possibilities }\end{array}$} & $\begin{array}{l}\text { Pearson } \\
\text { Correlation }\end{array}$ &, $621^{* *}$ &, $585^{* *}$ &, $717^{* *}$ & 1 &, $549^{* * *}$ &,$- 215^{* *}$ \\
\hline & $\begin{array}{l}\text { Sig. (2- } \\
\text { tailed) }\end{array}$ & ,000 & ,000 & ,000 & & ,000 & ,007 \\
\hline & $\mathrm{N}$ & 156 & 156 & 156 & 156 & 156 & 156 \\
\hline \multirow{3}{*}{ Colleagues } & $\begin{array}{l}\text { Pearson } \\
\text { Correlation }\end{array}$ &, $452^{* *}$ &, $369^{* *}$ &, $524^{* *}$ &, $549^{* *}$ & 1 &,- 040 \\
\hline & $\begin{array}{l}\text { Sig. (2- } \\
\text { tailed) }\end{array}$ & ,000 & ,000 & ,000 & ,000 & & ,622 \\
\hline & $\mathrm{N}$ & 156 & 156 & 156 & 156 & 156 & 156 \\
\hline
\end{tabular}

**. Correlation is significant at the 0.01 level (2-tailed).

*. Correlation is significant at the 0.05 level (2-tailed). 
In addition, mean values of employees' organizational stress is observed as 3,57. Research results also point out that stress perceptions of employees about managers, tangible possibilities and colleagues appeared to be high when compared to other sub-dimensions of stress perceptions.

Table 3 indicates that according to correlation analysis results there is a statistically significant relationship between stress perception about tangible possibilities and organizational identification $(r=-, 215 ; p=0,007)$. Moreover, there is no any statistically significant relationship among other sub-dimensions of organizational stress and organizational identification. Thus, $\mathrm{H} 4$ hypothesis (There is a negative relationship between employees' colleagues and organizational identification) is rejected.

Table 4. Regression Model to Estimate the Organizational Identification

\begin{tabular}{|c|c|c|c|c|}
\hline Model & R & R Square & Adjusted R Square & Std.Error of the Estimate \\
\hline 1 &, $349^{\mathrm{a}}$ &, 122 &, 092 &, 88711 \\
\hline
\end{tabular}

a. Predictors: (Constant), Nature of Existing Job, Managers, Promotion, Tangible Possibilities, Colleagues

It is pointed out in Table 4 that the correlaiton coefficient of sub-dimensions of stress and organizational identification is $(r=0,349)$ and determination coefficient is $\left(\mathrm{R}^{2}=0,122\right)$. It is also observed that there is $12,2 \%$ effect of stress perception of employees on organizational identification.

Table 5. Coefficients ${ }^{\mathrm{a}}$

\begin{tabular}{|c|c|c|c|c|c|}
\hline \multirow[t]{2}{*}{ Model } & \multicolumn{2}{|c|}{ Unstandardized Coefficients } & \multirow{2}{*}{\begin{tabular}{|l|}
$\begin{array}{c}\text { Standardized } \\
\text { Coefficients }\end{array}$ \\
Beta
\end{tabular}} & \multirow[t]{2}{*}{$\mathbf{t}$} & \multirow[t]{2}{*}{ Sig. } \\
\hline & B & Std. Error & & & \\
\hline (Constant) & 3,949 &, 368 & & 10,725 &, 000 \\
\hline $\begin{array}{l}\text { Nature of } \\
\text { Existing Job }\end{array}$ &, 112 &, 094 &, 120 & 1,189 &, 236 \\
\hline Managers &,- 239 & 102 &,- 235 & $-2,357$ &, 020 \\
\hline Promotion & 138 &, 114 &, 142 & 1,207 &, 229 \\
\hline $\begin{array}{l}\text { Tangible } \\
\text { Possibilities }\end{array}$ &,- 287 &, 114 &,- 316 & 2,507 &, 013 \\
\hline Colleagues &,- 349 &, 130 &,- 255 & $-2,692$ & ,008 \\
\hline
\end{tabular}

a. Dependent Variable: Organizational Identification

According to regression coefficient values of sub-dimensions of organizational stress as shown on Table 5, managers $(\mathrm{p}=, 020)$, Tangible Possibilities $(\mathrm{p}=, 013)$ and colleagues $(\mathrm{p}=, 008)$ dimensions have statistical significance with negative effect on organizational identification. In this context, there is a negative correlation among stress perception of employees on colleagues, tangible possibilities, managers and organizational identification. In addition, dimensions that negatively affect organizational identification are observed as stress caused ffrom colleagues $(\beta=-349)$, stress caused from tangible possibilities $(\beta=-287)$ and stress caused from managers $(\beta=-239)$. Therefore, H7, H9 and H10 hypotheses are accepted.

\section{Conclusion}

The main objective of this research is to determine the effects of stress factors on the organizational identification process of shopping center employees in Ankara. Research results figure out that there is a statistically significant negative relationship between stress perceptions on tangible possibilities $(r=-, 215$; $\mathrm{p}=0,007$ ) and organizational identification. Furthermore, it is also observed that stress perception of 
employees on colleagues $(\beta=-349)$, on tangible possibilities $(\beta=-287)$ and on managers $(\beta=-239)$ negatively affect organizatinal identification. Human resources is of great importance for each organization dealing with service sector. Providing maximum productivity from current human resources play a significant role on sustainability of both competitive advantage and the organizational existence of the organizations. Organizations can provide considerable contribution and evaluate the potential more efficiently in case they cut down the pressure on human resources and establish the satisfaction of employees.

Therefore, it is vital for managers to rationally govern the stress factors and provide employees' organizational identification in order to sustain employees' health. In this context, providing a satisfying wage level and fair performance evaluation system for employees is of great importance. Additionally, managers need to establish effective communication system among managers and employees, consider employees' thoughts and ensure normal working hours to get a better perception of organizational integration. Providing necessary resources and environment to employees for improving their abilities and establishing sufficient break time is another outstanding matter for managers. Moreover, positive behaviors and unaccepted behaviors should be precisely specified according to organizational policies and procedures. Employees need to realize their responsibilities and duties in a clear circumstance not to cause a conflict among eachother. Establishing the team awareness in the organizational structure and consolidating the friendship among employees also should not be disregarded.

\section{References}

Altan, S. (2018). Örgütsel yapıya bağlı stres kaynakları ve örgütsel stresin neden olduğu başlıca sorunlar. Stratejik ve Sosyal Araştırmalar Dergisi, 2(3), 137-158.

Ataman, G. (2001). İşletme Yönetimi: Temel Kavramlar ve Yaklaşımlar,Türkmen Kitabevi, İstanbul.

AYD,(2019). http://www.ayd.org.tr

Başol, O., Saruhan, O. (2018). Alışveriş Merkezi Çalışanlarının Çalışma Koşullarının İnsan Onuruna Yakışır İş Bağlamında Değerlendirilmesi: Nitel Bir İnceleme. Kocaeli Üniversitesi Sosyal Bilimler Dergisi, (36), 122-147.

Coetzee, M., van Dyk, J. (2018). Workplace bullying and turnover intention: Exploring work engagement as a potential mediator. Psychological reports, 121(2), 375-392.

Cranwell-Ward, J., Abbey, A. (2005). Organizational stress. Springer, Great Britain.

Elsbach, K. D. (1999). An expanded model of organizational identification. Research in Organizational Behavior, 21, 163-200.

Eren, E. (2010), Örgütsel Davranış ve Yönetim Psikolojisi, Beta ,İstanbul.

Fletcher, D., Hanton, S., Mellalieu, S. D. (2006). An organizational stress review: Conceptual and theoretical issues in competitive sport. Literature Reviews In Sport Psychology, 321373.

Fonner, K. L., \& Roloff, M. E. (2012). Testing the connectivity paradox: Linking teleworkers' communication media use to social presence, stress from interruptions, and organizational identification. Communication Monographs, 79(2), 205-231.

Ganster, D. C., Mayes, B. T., Sime, W. E., Tharp, G. D. (1982). Managing organizational stress: A field experiment. Journal of Applied Psychology, 67(5), 533-542.

Garg, N., \& Saxena, A. (2020). Promoting Constructive Deviance as an Antidote to Organizational Stress. In Analyzing Workplace Deviance in Modern Organizations (pp. 139-158). IGI Global.

Güney, S. (2011), Örgütsel Davranış, Nobel, İstanbul.

Gürlek,M., Tuna, M. (2018). Sosyal Kimlik Teorisi Açısından Örgütsel Özdeşleşmenin Teorik Temelleri, 2(3), 39-48.

Hall, D. T., Schneider, B., Nygren, H. T. (1970). Personal factors in organizational identification. Administrative science quarterly, 176-190.

Houkes, I., Janssen, P. P., de Jonge, J., Nijhuis, F. J. (2001). Specific relationships between work characteristics and intrinsic work motivation, burnout and turnover intention: A multi-sample analysis. European Journal of Work and Organizational Psychology, 10(1), 1-23. 
Jain, A. K., Cooper, C. L. (2012). Stress and organisational citizenship behaviours in Indian business process outsourcing organisations. IIMB Management Review, 24(3), 155-163.

Khusainova, R., de Jong, A., Lee, N., Marshall, G. W., \& Rudd, J. M. (2018). (Re) defining salesperson motivation: current status, main challenges, and research directions. Journal of Personal Selling \& Sales Management, 38(1), 2-29.

Kreiner, G. E., \& Ashforth, B. E. (2004). Evidence toward an expanded model of organizational identification. Journal of Organizational Behavior: The International Journal of Industrial, Occupational and Organizational Psychology and Behavior, 25(1), 1-27.

Mael, F. A., Ashforth, B. E. (1995). Loyal from day one: Biodata, organizational identification, and turnover among newcomers. Personnel psychology, 48(2), 309-333.

Mael, F., \& Ashforth, B. E. (1992). Alumni and their alma mater: A partial test of the reformulated model of organizational identification. Journal of organizational Behavior, 13(2), 103-123.

Maertz Jr, C. P., \& Griffeth, R. W. (2004). Eight motivational forces and voluntary turnover: A theoretical synthesis with implications for research. Journal of management, 30(5), 667-683.

Riketta, M. (2005). Organizational identification: A meta-analysis. Journal of vocational behavior, 66(2), 358-384.

Smidts, A., Pruyn, A. T. H., \& Van Riel, C. B. (2001). The impact of employee communication and perceived external prestige on organizational identification. Academy of Management journal, 44(5), 1051-1062.

Solakoğlu, İ., (2007). İşletmelerde mobbing'in örgütsel stresle ilişkisi ve bir sağlık kuruluşunda uygulama (Yayımlanmamış yüksek lisans tezi). Dumlupınar Üniversitesi Sosyal Bilimler Enstitüsü İşletme Anabilim Dalı, Kütahya.

Sullivan, S. E., Bhagat, R. S. (1992). Organizational stress, job satisfaction and job performance: where do we go from here?. Journal of management, 18(2), 353-374.

Tavakoli, M. (2010). A positive approach to stress, resistance, and organizational change. Procedia-Social and Behavioral Sciences, 5, 1794-1798.

Uzunsakal, E., Yıldız, D. (2018), Alan araştırmalarında güvenilirlik testlerinin karşılaştırılması ve tarımsal veriler üzerine bir uygulama, Uygulamall Sosyal Bilimler Dergisi, C:2, S:1, ss.14-28.

Van Knippenberg, D., Van Schie, E. C. (2000). Foci and correlates of organizational identification. Journal of occupational and organizational psychology, 73(2), 137-147.

Weinberg, A., Bond, F., Cooper, C., Sutherland, V. J. (2010). Organizational stress management: A strategic approach. Palgrave Macmillan.

Woodman, T., Hardy, L. (2001). A case study of organizational stress in elite sport. Journal of applied sport psychology, 13(2), 207-238.

Yamuç, V. A., Türker, D. (2015). Örgütsel stres kaynaklarının analizi: Bir üretim işletmesinde kadın ve erkek çalışanlar üzerine inceleme. Yönetim Bilimleri Dergisi, 13(25), 389-423.

$\mathrm{Yu}$, M. C. (2009). Employees' perception of organizational change: The mediating effects of stress management strategies. Public Personnel Management, 38(1), 17-32. 